\title{
ANALISIS STRUKTUR, PERILAKU, DAN KINERJA PEMASARAN KENTANG GRANOLA DI KECAMATAN PANGALENGAN, KABUPATEN BANDUNG, JAWA BARAT
}

\author{
Vela Rostwentivaivi Sinaga ${ }^{1)}$, Anna Fariyanti ${ }^{2)}$ dan Netti Tinaprilla ${ }^{3)}$ \\ ${ }^{1,2,3)}$ Magister Sains Agribisnis, Fakultas Ekonomi dan Manajemen, Institut Pertanian Bogor \\ ${ }^{1)}$ velasinaga@gmail.com
}

\begin{abstract}
High number of production and vast planting area make Pengalengan as granola potato production center of Bandung Regency. Problems faced by potato farmers of the area are price volatility, limited market information, and middleman controlled market. The purpose of this study is to analyze granola potatoes market structure, conduct, and performance at Pangalengan. The methods used are market concentration and market entry and exit barriers to analyze market structure; marketing function (exchange, physical and facilities) to analyze market conduct; and farmer share and marketing margin to analyze market performance. The result shows granola potato market has nine marketing channel, oligopsony market, farmer position as price taker and middleman caused barrier to entry and relatively efficient market performance with an average value of 27,64 percent and an average farmer share of 72,36 percent.
\end{abstract}

Keyword(s): Market Structure-Conduct-Performance, granola potato.

\begin{abstract}
ABSTRAK
Tingginya produksi dan luas area tanam membuat Pangalengan menjadi sentra produksi kentang di Kabupaten Bandung. Masalah yang dihadapi oleh petani kentang adalah ketidakstabilan harga, terbatasnya informasi pasar, serta pasar yang dikendalikan oleh pedagang pengumpul. Tujuan penelitian ini adalah menganalisis struktur, perilaku dan kinerja pasar kentang granola di Kecamatan Pangalengan. Metode penelitian yang digunakan adalah struktur pasar yang dianalisis dengan konsentrasi pasar dan hambatan keluar masuk pasar; perilaku pasar yang dianalisis dengan tiga fungsi pemasaran (pertukaran, fisik dan fasilitas) dan kinerja pasar yang dianalisis dengan farmer share dan marjin pemasaran. Hasil penelitian menunjukkan bahwa pemasaran kentang granola memiliki sembilan saluran pemasaran, pasar bersifat oligopsoni, posisi petani sebagai penerima harga dan adanya hambatan masuk pasar karena peranan pedagang pengumpul. Pasar menunjukkan kinerja yang relatif efisien dengan nilai margin ratarata sebesar 27,64 persen dan farmer share rata-rata sebesar 72,36 persen
\end{abstract}

Kata Kunci: Struktur-Perilaku-Kinerja Pasar, kentang granola

\section{PENDAHULUAN}

Hortikultura memegang peranan penting dalam sektor pertanian dan perekonomian nasional yang dapat dilihat dari nilai Produk Domestik Bruto (PDB).
Hortikultura memiliki beberapa keunggulan, yaitu: 1) keragaman jenis, 2) ketersediaan sumberdaya lahan dan teknologi, 3) potensi serapan pasar di dalam negeri maupun internasional yang 
terus meningkat, 4) nilai ekonomi yang tinggi, serta 5) sumber pendapatan khususnya bagi petani. Pasokan hortikultura (buah-buahan, sayuran, tanaman hias, dan tanaman biofarmaka) diarahkan untuk memenuhi kebutuhan konsumen dalam negeri, pasar tradisional, pasar modern, serta ekspor. Selain memegang bagian terpenting dari keseimbangan pangan, komoditas hortikultura harus tersedia setiap saat dalam jumlah yang cukup, mutu baik, aman konsumsi, harga terjangkau, dan mampu diakses oleh seluruh lapisan masyarakat (Ditjen Hortikultura, 2014).

Kontribusi PDB hortikultura khususnya sayuran merupakan terbesar kedua setelah buah-buahan. Selama kurun waktu 5 tahun, nilai PDB sayuran selalu meningkat dari tahun 2005 sebesar 22,63 triliyun rupiah, tahun 2006 sebesar 24,69 triliyun rupiah, tahun 2007 sebesar 25,59 triliyun rupiah, tahun 2008 sebesar 28,21 triliyun rupiah dan tahun 2009 sebesar 30,51 triliyun rupiah (Ditjen
Hortikultura, 2010). Nilai PDB Hortikultura tahun 2005-2009 dapat dilihat pada Gambar 1.

Kentang tersebar di enam provinsi dengan share kumulatif sebesar 92,81 persen, diantaranya Jawa Barat dengan share sebesar 25,57 persen, Jawa Tengah 24,63 persen, Sulawesi Utara 11,91 persen, Sumatera Utara 11,91 persen, Jawa Timur 11,08 persen, dan Jambi 7,70 persen (Pusdatin, 2013).

Terdapat 4 kabupaten di Jawa Barat yang merupakan sentra kentang, diantaranya Bandung, Garut, Majalengka, dan Kuningan (Ditjen Hortikultura, 2012). Diantara empat kabupaten tersebut, Kabupaten Bandung yang memiliki luas dan produksi terbesar, yaitu 6.856 ha dan 1.318.757 ton. Varietas kentang yang banyak dibudidayakan adalah granola. Sentra kentang granola berada di Kabupaten Bandung, tepatnya di Kecamatan Pangalengan yang merupakan kawasan agropolitan, yaitu kawasan yang sebagian besar masyarakatnya

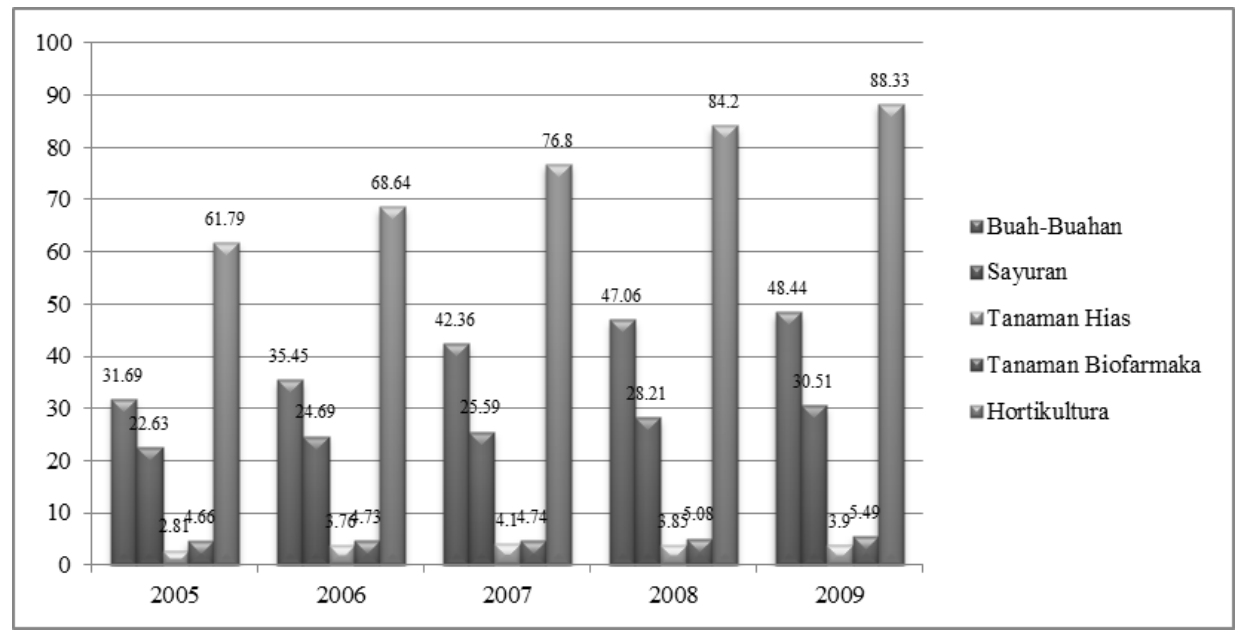

Sumber : Ditjen Hortikultura, 2010

Gambar 1. Nilai PDB Hortikultura Tahun 2005-2009 (Triliyun Rupiah) 
bermatapencaharian sebagai petani dan terdapat kegiatan pengolahan skala rumah tangga. Kecamatan Pangalengan dapat memberikan kontribusi bagi pemenuhan kebutuhan kentang sebesar 60 persen untuk Kabupaten Bandung. Selain sebagai komoditas unggulan di Kecamatan Pangalengan, kentang juga merupakan komoditas sayuran unggulan di Indonesia.

Bila dilihat dari aspek pasar, harga kentang di Jawa Barat tahun 2008-2012 mengalami peningkatan, masing-masing 4,92 persen (produsen) dan 9,18 persen (konsumen). Harga kentang di tingkat konsumen terus meningkat dari tahun 2008-2011 sebesar Rp 4.402/kg menjadi Rp 8.086/kg dan menurun sebesar Rp $7.261 / \mathrm{kg}$ pada tahun 2012 . Harga ratarata kentang tingkat konsumen sebesar Rp 6.279/kg dan tingkat produsen sebesar Rp 3.967/kg. Perkembangan harga kentang tingkat produsen dan konsumen di Provinsi Jawa Barat tahun 2008-2012 dapat dilihat pada Gambar 2.
Harga tingkat produsen dan konsumen yang cukup jauh ini membuat posisi tawar petani lemah dalam menentukan harga di pasar. Tidak hanya itu, akses informasi harga, keterikatan dengan bandar (pedagang pengumpul), teknologi yang digunakan masih sederhana, peranan kelompok tani yang belum maksimal, hingga akses permodalan yang terbatas (Chan, 2007; Higgins et al., 2007; Pietrobelli dan Rabellotti, 2011). Irawan et al., (2001) menjelaskan bahwa pemasaran pertanian khususnya hortikultura masih menjadi bagian yang lemah dalam aliran komoditas karena belum berjalan secara efisien. Hal ini dapat terlihat dari pendistribusian kentang yang dilakukan oleh petani di Pangalengan kepada lembaga pemasaran yang masih terbatas. Pendisitribusian hasil panen dilakukan secara langsung kepada pihak bandar atau pedagang pengumpul. Sulitnya menembus pedagang besar membuat pemasaran kentang granola melalui tahapan pemasaran yang cukup panjang.

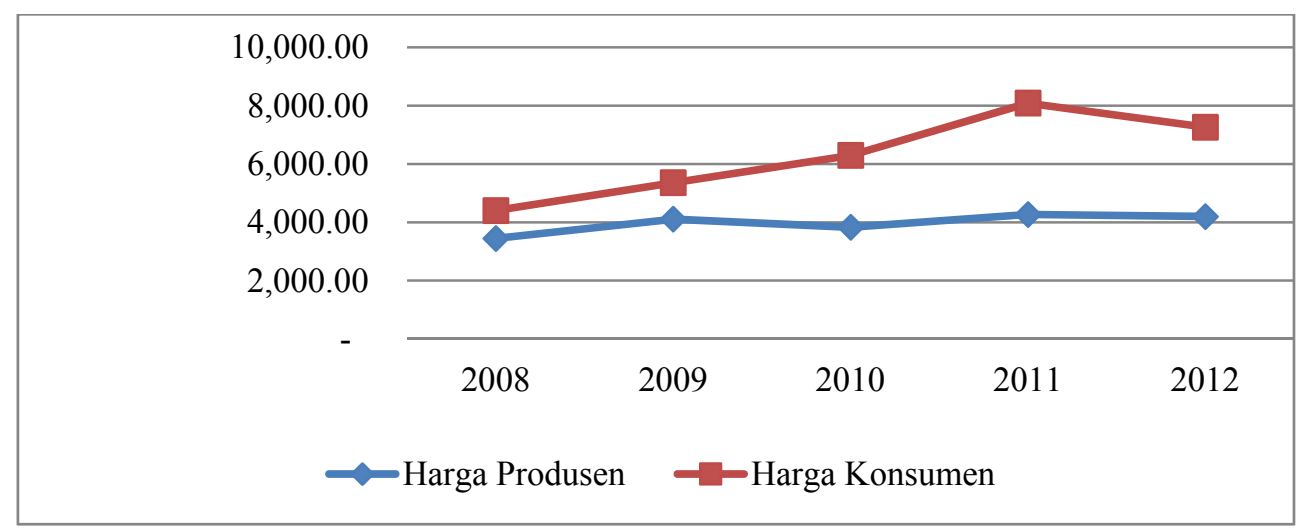

Sumber : Pusdatin, 2013

\section{Gambar 2. Harga Produsen dan Konsumen Kentang di Indonesia} Tahun 2008-2012 
Fluktuasi harga pada produk pertanian menjadi permasalahan utama dalam sistem pemasaran (Agustian dan Mayrowani, 2008; Irawan, 2007). Seringkali petani mengalami kerugian akibat fluktuasi harga. Fluktuasi harga dapat terjadi karena produksi kentang hanya terkonsentrasi pada daerah-daerah tertentu, pola produksi yang tidak sesuai, fasilitas yang tidak memadai, hingga panjangnya rantai pemasaran kentang (Irawan, 2007; Sukayana, Darmawan, dan Wijayanti, 2013). Fluktuasi harga di beberapa pasar induk dapat dilihat pada Gambar 3.

Perubahan harga disebabkan oleh struktur, perilaku, dan kinerja pemasaran. Proses pemasaran saat ini tidak hanya mendistribusikan barang sampai ke tangan konsumen saja, melainkan diperlukan koordinasi serta kolaborasi diantara lembaga pemasaran, agar produk mampu didistribusikan tepat waktu, jumlah, tempat, serta kepemilikan. Apabila salah satu rantai mengalami gangguan maka mempengaruhi rantai lainnya.

Kontinyuitas, pemenuhan pasokan, serta sistem pembayaran, dan usaha pengolahan masih dirasakan sulit bagi petani kentang granola. Petani ini masih tergantung dengan adanya keberadaan bandar sebagai lembaga pemasaran yang menampung hasil panennya. Kondisi pemasaran yang tidak efisien ini membuat petani sulit meningkatkan pendapatan serta kesejahteraan. Panjangnya rantai dalam lembaga pemasaran kentang granola membuat sebagian pelaku saja yang mendapatkan marjin pemasaran yang lebih tinggi. Tinggi rendahnya harga yang diterima petani erat kaitannya dengan struktur pasar dan besarnya marjin pemasaran sehingga untuk meningkatkan pemasaran petani kentang dapat dicapai apabila struktur pasar dan penyebab tingginya marjin pemasaran dapat diketahui.

Kompleksitas yang terjadi dalam sistem pemasaran membuat penelitian ini

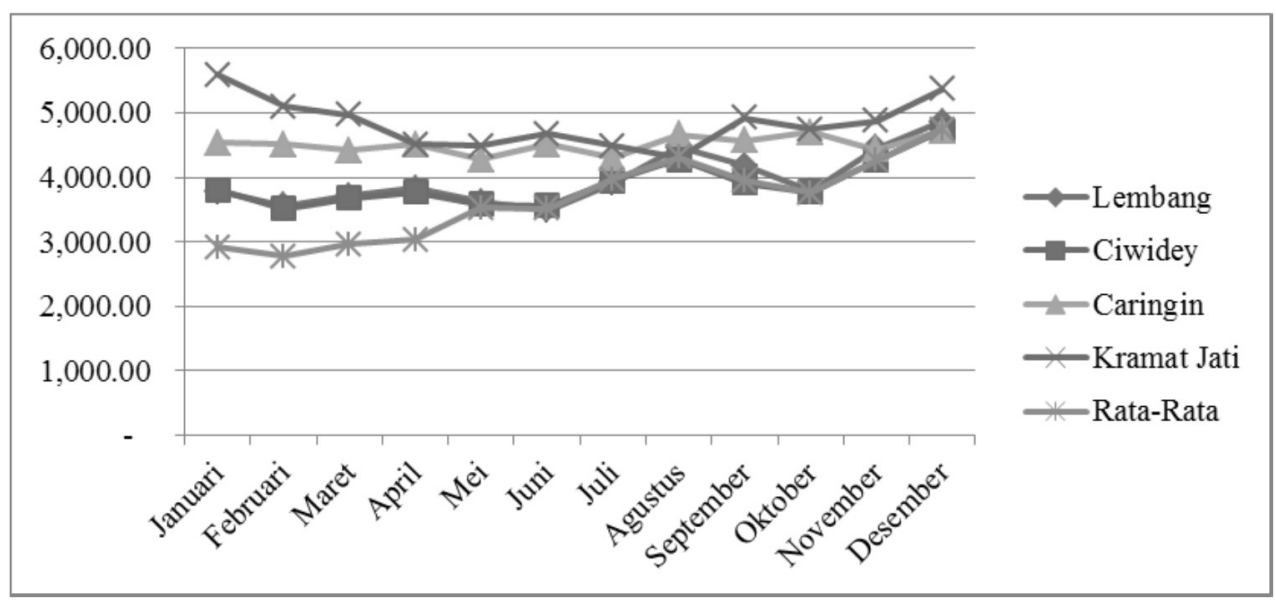

Sumber : Dinas Pertanian Tanaman Pangan Provinsi Jawa Barat, 2012

Gambar 3. Harga Kentang di Beberapa Pasar Induk Tahun 2012 
penting untuk dikaji secara mendalam. Adapun tujuan dari penelitian ini adalah menganalisis struktur, perilaku, dan kinerja pasar kentang granola di Kecamatan Pangalengan.

\section{KERANGKA PEMIKIRAN}

Struktur, perilaku, dan kinerja pasar merupakan pendekatan yang dilakukan untuk memecahkan permasalahan khususnya dalam pemasaran produk pertanian. Permasalahan yang dirasakan adalah margin pemasaran yang tinggi, fluktuasi harga, risiko produk pertanian segar yang masih rendah, hingga pada pengolahan produk pertanian segar yang masih jarang terlihat.

Baye (2010) menjelaskan struktur pasar dapat dianalisis dengan Four Firm Concentration Ratio (CR 4) dan Hirchman Ferfindahl Index (HHI). Perbedaan CR 4 dan HHI adalah jika CR 4 menunjukkan 4 perusahaan besar diantara 50-75 persen dan HHI jika berada di 1.0001.800 dimana pasar cenderung terkonsentrasi dengan tingkat persaingan yang kecil. Hirscey (2009) menjelaskan CR 8 dengan kriteria jika CR $8 \geq 0,8$ menunjukkan usaha terkonsentrasi kuat. Jika nilai CR 8 antara $0,5<$ CR $8<0,8$ menunjukkan pasar terkonsentrasi sedang dan nilai $\mathrm{CR} \quad 8 \leq 0,5$ menunjukkan pasar terkonsentrasi lemah. Struktur pasar juga dapat melihat hambatan masuk dan keluar pasar dimana dapat dihitung dengan Minimum Efficiency Scale (MES) yaitu perhitungan dari pembelian komoditas terbesar terhadap total komoditas dari daerah tertentu.

Kohls dan Uhl (2002) menjelaskan struktur pasar sebagai karakteristik organisasi yang menentukan hubungan antara penjual dan pembeli yang dapat dilihat dari banyaknya jumlah penjual, produk yang homogen, masuknya perusahaan baru dalam pasar, serta kemampuan dalam menentukan harga. Struktur pasar ini berpengaruh pada perilaku dan kinerja pasar (Cramer et al. 2001), dimana tipe pasar dibagi menjadi 2 bagian, yaitu persangan sempurna dan persaingan tidak sempurna (oligopoli, oligopsoni, dan monopoli).

Perilaku pasar adalah aktivitas yang dilakukan dalam pasar dengan melibatkan fungsi-fungsi pemasaran seperti fungsi pertukaran, fisik, dan fasilitas. Dahl dan Hammond (1977) mendefinisikan perilaku pasar sebagai pola tingkah laku dari lembaga-lembaga pemasaran dalam struktur pasar tertentu yang meliputi kegiatan pembelianpenjualan, penentuan dan pembentukan harga, kerjasama lembaga pemasaran, serta praktek fungsi pemasaran. Perilaku pasar juga membutuhkan informasi yang transparan khususnya pada harga komoditas. Perilaku petani dalam sektor pertanian jarang melakukan sortasi, grading, pengemasan ataupun perlakuan lain yang mengakibatkan harga yang diterima petani lebih kecil. Dengan adanya kegiatan sortasi, grading hingga pengemasan sebenarnya dapat meningkatkan harga jual produk.

Struktur, perilaku, dan kinerja memiliki keterkaitan satu sama lain dalam pemasaran. Analisis kinerja pasar dapat dihitung dengan marjin dan farmer share. Perhitungan ini dilakukan untuk melihat perbedaan harga yang dibayarkan konsumen dengan harga yang diterima 
oleh petani. Marjin pemasaran menurut Tomek dan Robinson (1990) memberikan 2 alternatif, yaitu perbedaan harga yang dibayarkan konsumen dengan harga yang diterima produsen dan harga dari kumpulan jasa-jasa pemasaran sebagai akibat adanya permintaan dan penawaran jasa-jasa pemasaran tersebut. Asmarantaka (2012) menjelaskan konsep marjin pemasaran merupakan perbedaan harga di tingkat petani produsen dengan harga di tingkat konsumen akhir atau di tingkat retail. Marjin adalah pendekatan keseluruhan dari sistem pemasaran produk pertanian, mulai dari tingkat petani sebagai produsen primer sampai produk tersebut di tangan konsumen akhir sehingga sering dikatakan sebagai Marjin Pemasaran Total (MT).

Marjin dapat memberikan gambaran terhadap aktivitas yang dilakukan pelaku usaha dalam sistem pemasaran, yaitu kumpulan balas jasa karena kegiatna produktif (menambah atau menciptakan nilai guna) dalam mengalirnya produkproduk agribisnis mulai dari tingkat petani sampai konsumen akhir. Marjin juga dapat menunjukkan nilai tambah dalam produk agribisnis baik di tingkat petani (produsen) hingga konsumen akhir. Tidak hanya dipakai sebagai indikator efisiensi sistem pemasaran, marjin dapat juga mengevaluasi fungsi-fungsi pema- saran yang terjadi dan kepuasan konsumen atau produk akhir harus setara.

Kohls dan Uhl (2002) menjelaskan farmer share sebagai persentase harga yang diterima oleh petani dengna harga yang dibayarkan konsumen. Asmarantaka (2012) menjelaskan bahwa marjin pemasaran yang tinggi atau farmer share yang turun tidak selalu menunjukkan dari harga di tingkat petani, penerimaan petani, efisiensi pemasaran. Analisis marjin pemasaran yang tinggi, farmer share yang rendah, serta panjangnya saluran pemasaran tidak selalu menunjukkan bahwa pemasaran tidak efisien. Asmarantaka (2012) juga menekankan bahwa efisiensi pemasaran harus memperhitungkan fungsi-fungsi pemasaran yang ada, biaya-biaya dan atribut produk. Jika rantai pemasaran panjang dan mampu meningkatkan kepuasan konsumen maka dapat dikatakan bahwa sistem pemasaran tersebut efisien. Adapun keterkaitan antara struktur, perilaku dan kinerja pasar dapat dilihat pada Gambar 4.

\section{METODE PENELITIAN}

\section{Lokasi dan Waktu Penelitian}

Penelitian dilakukan di sentra kentang di Kabupaten Bandung, yaitu Kecamatan Pangalengan dengan dua desa sebagai fokus penelitian, yaitu Desa

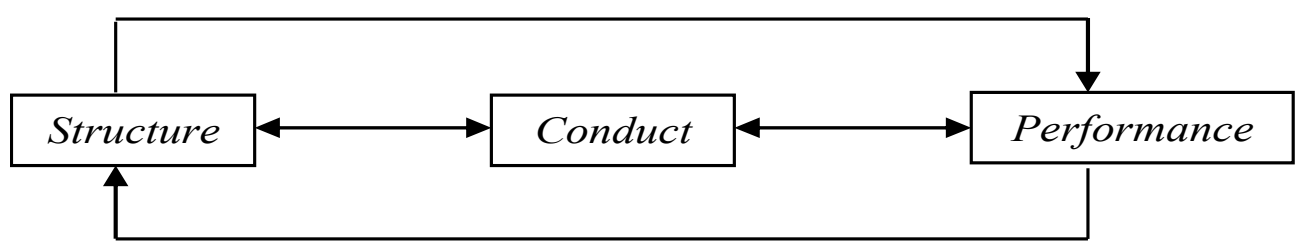

Gambar 4. Hubungan keterkaitan antara structure, conduct, dan performance 
Margamekar dan Pulosari. Lokasi dipilih secara purposive (sengaja) atas pertimbangan bahwa dua desa ini letaknya berdekatan, memiliki banyak petani yang mengusahakan kentang granola serta memiliki luas lahan dan produksi kentang yang cukup tinggi. Penelitian dilakukan pada bulan Desember 2013-Januari 2014.

\section{Metode Pengambilan Responden}

Pemilihan responden, yaitu petani di Desa Margamekar dan Pulosari dipilih berdasarkan rekomendasi dari penyuluh lapangan yang ada di kedua desa tersebut dan teknik pengambilan sampel pelaku usaha pemasaran kentang granola dengan cara snowball sampling. Adapun jumlah responden dalam penelitian ini sebagai berikut :

Tabel 1. Jumlah Responden

\begin{tabular}{lr}
\hline \multicolumn{1}{c}{ Responden } & Jumlah \\
\hline Petani Margamekar & 30 \\
Petani Pulosari & 30 \\
Bandar & 10 \\
Pedagang pasar & 5 \\
Pedagang pengecer & 8 \\
Pedagang sayur keliling & 2 \\
\hline Total & 85 \\
\hline
\end{tabular}

\section{Metode Analisis Data}

Metode analisis yang digunakan dalam penelitian ini adalah analisis saluran pemasaran, analisis struktur pasar (konsentrasi pasar dan hambatan keluar masuk pasar), analisis perilaku pasar, dan analisis kinerja pasar (farmer share dan marjin pemasaran).

\section{Analisis Struktur Pasar}

Analisis struktur pasar dapat dilihat dari :

\section{Konsentrasi Pasar}

Konsentrasi pasar dapat dihitung dengan CR 8 (Eight Firm Concentration Rasio) yang merupakan metode analisis dengan tujuan untuk melihat output yang mampu dihasilkan oleh 8 bandar di Kecamatan Pangalengan. Hirschey (2009) menjelaskan nilai $\mathrm{CR} \quad 8 \geq 0,8$ menunjukkan industri terkonsentrasi kuat. Untuk nilai CR 8 antara $0.5<$ CR $8<0,8$ menunjukkan pasar terkonsentrasi sedang, dan nilai CR $8 \leq 0,5$ menunjukkan pasar terkonsentrasi lemah. Rumus konsentrasi pasar, yaitu :

$$
\mathrm{CR8}=\frac{\mathrm{S1}+\mathrm{S2}+\mathrm{S3}+\mathrm{S4}+\mathrm{S5}+\mathrm{S6}+\mathrm{S} 7+\mathrm{S8}}{\mathrm{ST}}
$$

Keterangan :

$\mathrm{CR} 8=$ Konsentrasi rasio

S1 = Volume penjualan kentang oleh bandar 1 (ton/tahun)

Sn $\quad=$ Volume penjualan kentang oleh bandar ke-n (ton/tahun)

ST $=$ Total Penjualan seluruh kentang oleh bandar di Kecamatan Pangalengan (ton/tahun)

\section{Hambatan Keluar Masuk Pasar}

Hambatan keluar masuk pasar dapat dihitung dengan Minimum Efficiency Scale (MES), yaitu perhitungan penjualan kentang yang dilakukan oleh bandar terhadap total kentang di Kecamatan Pangalengan, Kabupaten Bandung. Hambatan masuk dapat dihitung dengan rumus:

$$
M E S=\frac{\text { Penjualan kentang olh bandar }}{\text { Jml kentang di Pengalengan }}
$$

Jika perhitungan menunjukkan lebih dari 10 persen maka diindikasikan 
bahwa pemasaran kentang terdapat hambatan masuk (Jaya, 2001).

\section{Analisis Perilaku Pasar}

Perilaku pasar merupakan aktivitasaktivitas yang terjadi di pasar. Perilaku pasar berkaitan erat dengan struktur pasar dan kinerja pasar. Dengan adanya struktur pasar dan perilaku pasar akan membentuk kinerja pasar. Kohls dan Downey (1972) menjelaskan 3 fungsi pemasaran dalam perilaku pasar, yaitu fungsi pertukaran, fisik dan fasilitas (penyediaan sarana).

\section{Fungsi Pertukaran}

Fungsi pertukaran adalah kegiatan yang menyangkut pengalihan hak kepemilikan barang dari satu pihak ke pihak lain. Dalam fungsi pertukaran terdiri dari penjualan dan pembelian.

\section{Fungsi Fisik}

Fungsi fisik adalah kegiatan yang melibatkan penanganan, gerakan, dan perubahan fisik produk. Terdapat 3 fungsi di dalam fungsi fisik, yaitu pengangkutan, penyimpanan, dan pemrosesan.

\section{Fungsi Fasilitas}

Fungsi fasilitas atau penyediaan sarana adalah kegiatan yang memperlancar fungsi pertukaran dan fisik dalam pemasaran, meliputi sortasi dan grading, informasi harga, penanganan risiko, dan pembiayaan.

Analisis Saluran Pemasaran merupakan perangkat organisasi yang saling bergantung satu sama lainnya, baik dalam menyediakan produk atau jasa yang digunakan oleh konsumen. Lembaga pemasaran bertujuan untuk memasarkan produk serta menyesuaikan permintaan dan penawaran. Saluran pemasaran yang efisien dapat mengurangi kesenjangan atau risiko yang akan terjadi, seperti risiko keterlambatan pengiriman maupun kesalahan tempat kepemilikan.

\section{Analisis Kinerja Pasar}

Kinerja pasar adalah keadaan sebagai akibat dari struktur dan perilaku pasar yang ditunjukkan dengan harga, biaya, dan volume produksi yang pada akhirnya dapat memberikan penilaian baik atau tidaknya suatu sistem pemasaran (Dahl dan Hammond, 1977)

Analisis kinerja pasar dapat dilihat dengan menghitung marjin pemasaran dan farmer share. Panjangnya saluran pemasaran yang ada belum tentu menunjukkan bahwa kinerja pemasaran tersebut tidak efisien. Jika rantai pemasaran panjang dan mampu meningkatkan kepuasan konsumen maka dapat dikatakan bahwa sistem pemasaran tersebut efisien.

\section{Marjin Pemasaran}

Asmarantaka (2012) menjelaskan definisi marjin sebagai cerminan dari aktivitas-aktivitas bisnis atau fungsifungsi pemasaran yang dilakukan dalam sistem pemasaran. Selain itu marjin adalah kumpulan balas jasa karena kegiatan produktif (menambah atau menciptakan nilai guna) dalam mengalirnya produk-produk agribisnis mulai dari petani sampai ke tangan konsumen akhir.

Marjin dapat menunjukkan nilai tambah dari petani hingga sampai di 
tangan konsumen. Analisis marjin ini dapat digunakan untuk menganalisis sistem pemasaran dari perspektif makro (pemasaran produk dari petani hingga konsumen). Adapun rumus dari marjin pemasaran dapat dilihat sebagai berikut:

$$
\mathbf{M T}=\mathbf{P r}-\mathbf{P f}
$$

Keterangan :

MT $=$ Marjin Total

$\mathrm{Pr}=$ Harga kentang di tingkat konsumen $(\mathrm{Rp} / \mathrm{kg})$

$\mathrm{Pf}=$ Harga kentang di tingkat petani $(\mathrm{Rp} / \mathrm{kg})$

\section{Farmer share}

Farmer share merupakan persentase harga yang diterima oleh petani dengan harga yang dibayarkan konsumen. Beberapa hal yang mempengaruhi farmer share, di antaranya tingkat pemrosesan, biaya transportasi, jumlah produk, dan keawetan produk. Farmer share berhubungan negatif dengan marjin pemasaran. Bila marjin pemasaran semakin tinggi, maka bagian yang diterima oleh petani semakin rendah. Farmer share dapat dihitung dengan rumus:

$$
F S=\frac{P_{f}}{P_{r}} \times 100 \text { persen }
$$

Keterangan :

FS $=$ Persentase yang diterima Petani

\section{HASIL DAN PEMBAHASAN Analisis Struktur Pasar}

\section{Konsentrasi Pasar}

Konsentrasi pasar dihitung dengan Eight Firm Concentration Ratio (CR 8) dengan menghitung penjualan yang dilakukan oleh bandar yang berada di Kecamatan Pangalengan selama satu tahun terakhir. Berdasarkan data Dinas
Pertanian Tanaman Pangan Provinsi Jawa Barat (2012) menyebutkan produksi kentang di Kabupaten Bandung mencapai 131.876 ton dan kontribusi Kecamatan Pangalengan sekitar 60 persen dari total produksi ke Kabupaten Bandung. Sehingga produksi total di Kecamatan Pangalengan mencapai 79.125,6 ton. Penelitian ini menghasilkan perhitungan bahwa dari total penjualan 8 bandar yang berada di Kecamatan Pangalengan selama 1 tahun terakhir adalah sebesar 23.256 ton.

Perhitungan berdasarkan hasil penelitian didapatkan bahwa konsentrasi rasio 8 bandar adalah terkonsentrasi lemah dengan nilai sebesar 0,29 atau 29 persen. Hal ini berarti bahwa 8 bandar tidak menguasai secara menyeluruh dari hasil penjualan kentang segar di Kecamatan ini. Terkonsentrasi lemah juga diindikasikan bahwa pasar yang memiliki banyak bandar dan memberikan peningkatan persaingan antara produsen untuk menjual kepada konsumen.

\section{Hambatan Keluar Masuk Pasar}

Hambatan masuk pasar dihitung dengan Minimum Efficiency Scale (MES), yaitu penjualan kentang oleh bandar dibagi dengan total kentang di kecamatan Pangalengan, Kabupaten Bandung, sehingga menghasilkan nilai sebesar 29 persen. Hal ini berarti adanya hambatan masuk karena nilai MES menunjukkan perhitungan lebih dari 10 persen. Hambatan masuk disebabkan oleh beberapa faktor, diantaranya :

1. Bandar memiliki modal yang cukup kuat. 
2. Akses kepada petani sebagai sumber input dan pedagang besar (pasar induk).

3. Informasi.

4. Kepercayaan diantara kedua belah pihak.

5. Ikatan psikologis antara bandar dan petani.

6. Bandar merupakan kaki tangan dari pedagang besar.

\section{Analisis Perilaku Pasar}

Perilaku pasar lebih menekankan pada aktivitas-aktivitas yang terjadi di pasar. Perilaku pasar sangat erat kaitannya dengan struktur dan kinerja pasar. Aktivitas yang terjadi di dalam pasar sangat dibutuhkan informasi serta kerjasama diantara lembaga pemasaran. Kohls dan Downey (1972) menjelaskan fungsi pemasaran yang dibagi menjadi tiga bagian, diantaranya fungsi pertukaran, fisik, dan penyediaan sarana atau fasilitas. Adapun pelaku di lembaga pemasaran kentang granola, diantaranya:

\section{Petani}

Petani berperan sebagai produsen kentang granola. Komoditas yang diusahakan adalah kentang granola dan beberapa komoditas sayuran lainnya, seperti kubis, tomat, cabai, buncis, jagung, dan komoditas sayuran lainnya. Aktivitas yang dilakukan oleh petani di Desa Margamekar dan Pulosari, diantaranya pembelian bibit, pengolahan lahan, penanaman, pengendalian hama penyakit, hingga kegiatan panen. Aktivitas ini masih dilakukan secara tradisional. Kentang dapat dipanen pada usia sekitar 100-120 hari.
Sebagian besar hasil panen didistribusikan langsung kepada bandar di Kecamatan Pangalengan. Penentuan harga berdasarkan kesepakatan kedua belah pihak (petani dan bandar). Dalam hal ini, petani hanya melakukan pengangkutan dan penyimpanan saja. Saat pengangkutan berlangsung, bandar melakukan pengecekan serta penimbangan hasil panen di tempat transaksi dan langsung didistribusikan kepada lembaga pemasaran lainnya untuk mengurangi penyusutan kentang. Penyediaan dana dilakukan petani dengan cara peminjaman kepada pihak lain, seperti bank dan bandar.

\section{Bandar atau pedagang pengumpul}

Bandar merupakan lembaga pemasaran yang berfungsi mengumpulkan hasil panen kentang dari produsen untuk didistribusikan secara langsung kepada pedagang besar, baik di pasar induk, luar kota, maupun perusahaan ekspor. Peranan bandar cukup besar sebagai penghubung antara petani dengan lembaga pemasaran berikutnya. Bandar juga memegang kepercayaan pedagang besar dalam memasok kebutuhannya sesuai dengan kualitas yang diinginkan dengan kesepakatan harga yang sudah ditetapkan sebelumnya. Tipe kentang yang didistribusikan diantaranya tipe $\mathrm{AB}$ dan ABC. Rata-rata pendistribusian hasil panen ke pasar adalah sebanyak 2-14 ton per satu kali pengiriman. Teknis pembelian kentang oleh bandar adalah pengambilan hasil panen kentang segar dari petani di tempat transaksi sesuai kesepakatan sebelumnya. Adapun pembayaran dapat dilakukan secara cash atau 
Down Payment (DP) terlebih dahulu dengan rata-rata pembayaran 3-30 hari dari awal pembelian. Bandar memegang kepercayaan petani dalam memasarkan produknya.

\section{Pedagang Besar}

Pedagang besar adalah lembaga pemasaran berikutnya setelah bandar. Aktivitas pedagang besar berada di pasar induk. Penelitian mengungkapkan bahwa kentang granola didistribusikan ke beberapa pasar induk, diantaranya Pasar Induk Caringin (Bandung), Pasar Induk Pangalengan (Pangalengan), Pasar Induk Kramat Jati (Jakarta), Pasar Induk Kemang (Bogor), dan Pasar Induk Tanah Tinggi (Tangerang).

Penjualan dilakukan pada malam hari hingga dini hari sekitar pukul 03.00 pagi. Penjualan kentang yang dilakukan pedagang besar cukup besar dari sisi kuantitasnya, berkisar 6,5-7,5 ton setiap hari (tergantung kondisi pasar). Jika kentang segar tidak habis dalam sehari, pedagang besar melakukan penyimpanan. Apabila kentang segar disimpan selama 3-4 hari maka pedagang besar akan melakukan sortasi untuk memisahkan antara kentang yang layak untuk dijual ataupun tidak.

\section{Pedagang Besar (Luar Kota)}

Sama halnya dengan pedagang besar di pasar induk. Pedagang besar di luar kota juga merupakan lembaga pemasaran yang membeli kentang Pangalengan. Harga jual kentang ke luar kota tidak jauh berbeda dengan harga di pasar induk, yaitu berkisar di Rp 6.400-6.800 per kg, bahkan ada yang mencapai Rp 7.000 per $\mathrm{kg}$ (tergantung kondisi maupun tipe kentang yang diperjualbelikan). Pembelian hasil panen rata-rata 7,5-14 ton per satu kali pengiriman. Distribusi dilakukan melalui jalur darat dan laut.

\section{Pedagang Pengecer}

Pedagang pengecer juga merupakan lembaga pemasaran yang memiliki peranan sebagai pembeli maupun penjual kentang. Pembelian kentang yang dilakukan oleh pedagang pengecer tidak sebanyak dengan pedagang besar. Pembelian hanya berkisar $25-1.000 \mathrm{~kg}$ (tergantung dari modal dan daya beli konsumen). Penjualan dilakukan di pasar tradisional yang relatif lebih kecil. Harga jual kentang jauh lebih mahal karena memperhitungkan kuantitas kentang yang dibeli dan jarak tempuh. Harga kentang berkisar di Rp 9.000 hingga Rp 12.000 per $\mathrm{kg}$. Sedangkan Sistem pembayaran dilakukan dengan 2 cara, yaitu pembayaran cash atau mengambil kentang terlebih dahulu baru dibayar kemudian hari.

\section{Pedagang Sayur Keliling}

Pedagang sayur keliling atau disebut juga dengan pedagang eceran kecil biasanya menjajakan jualannya di sekitar perumahan dengan menggunakan motor ataupun gerobak. Kuantitas penjualan kentang relatif sangat kecil, yaitu $8-10 \mathrm{~kg}$ per hari. Pedagang ini tidak hanya menjual kentang saja, melainkan sayuran lainnya. Harga jual kentang segar berkisar di harga Rp 12.000 per kg. Penjualan dilakukan pada pagi hingga siang hari. 
Terdapat 3 aktivitas pada fungsi pemasaran, yaitu fungsi pertukaran, fungsi fisik, dan fungsi fasilitas. Fungsi pertukaran terdiri dari aktivitas penjualan dan pembelian. Penjualan yang dilakukan petani dilakukan saat panen dan langsung didistribusikan kepada bandar ataupun ke pedagang besar. Petani memiliki hak untuk memilih bandar yang akan membeli hasil panennya dengan harga yang tertinggi. Harga jual ditetapkan berdasarkan kedua belah pihak antara petani dan bandar.

Kegiatan penjualan oleh petani dilakukan pada saat panen dan langsung didistribusikan kepada bandar ataupun langsung ke pedagang besar (pasar induk). Saat panen berlangsung, petani menghubungi bandar yang sudah dikenal ataupun bandar yang mencari siapa saja petani yang akan panen dalam waktu dekat. Petani memiliki hak untuk memilih bandar yang akan membeli hasil panennya berdasarkan harga tertinggi sesuai dengan informasi yang ada. Harga jual hasil panen berdasarkan kesepakatan yang ditetapkan oleh kedua belah pihak antara petani dan bandar.

Biaya transportasi yang dikeluarkan bandar untuk mendistribusikan ke pedagang besar (pasar induk) berkisar Rp 300.000 sampai Rp 1.300.000 per satu kali pengiriman (tergantung alat transportasi dan jarak tempuh). Sedangkan biaya transportasi ke pedagang besar (luar kota) mencapai biaya Rp 1.000.000 sampai Rp 3.000.000 per satu kali pengiriman.

Pengangkutan yang dilakukan petani mulai dari lahan hingga ke tempat transaksi (pinggir jalan) sesuai dengan perjanjian. Jika lahan ke tempat transaksi tersebut jauh biasanya dikenakan biaya pikul sesuai dengan jarak tempuh, ratarata biaya pikul per karung (50 kg) mencapai Rp 1.000-5.000 dan menjadi tanggungan petani. Selanjutnya bandar mengangkut dengan menggunakan truk double yang memuat kapasitas maksimal sebesar 7,5 ton. Beberapa bandar ada yang memiliki truk sendiri ataupun ada yang menyewa. Penyimpanan hasil panen terkadang dilakukan oleh lembaga pemasaran, mulai dari petani hingga ke pedagang sayur keliling. Bila hasil panen tersebut tidak habis dalam satu hari maka akan disimpan untuk penjualan hari berikutnya. Setelah penyimpanan lebih dari 3 hari, maka kentang harus disortir kembali untuk memisahkan kentang yang bagus dengan yang kurang baik. Hal ini dilakukan untuk mengurangi risiko penjualan kentang dengan kualitas yang rendah. Lembaga pemasaran mulai dari petani hingga ke pedagang sayur keliling tidak melakukan pemrosesan kentang segar menjadi produk olahan, dikarenakan pemasaran ini berfokus pada distribusi kentang segar dari petani hingga kepada konsumen.

Modal merupakan aspek penting dalam pemasaran. Berdasarkan hasil penelitian didapatkan bahwa membudidayakan kentang membutuhkan modal yang besar bila dibandingkan dengan komoditas sayuran lainnya, yaitu sebesar 60 juta rupiah per ha. Salah satu yang menyebabkan tingginya biaya produksi adalah obat-obatan dan pupuk. Tingginya modal yang dibutuhkan membuat para petani mencari cara untuk dapat menjalankan usahanya, yaitu dengan 
peminjaman modal kepada bank atau mengumpulkan modal dengan beberapa rekan untuk melaksanakan usaha bersama, ataupun dengan peminjaman kepada pihak lain. Adapun sumber modal oleh petani, lembaga pemasaran, maupun usaha pengolahan dapat dilihat pada Tabel 2.

Tabel 2. Sumber Modal Petani, Lembaga Pemasaran dan Usaha Pengolahan

\begin{tabular}{clr}
\hline No. & Sumber Modal & \multicolumn{1}{c}{$\begin{array}{c}\text { Persentase } \\
(\%)\end{array}$} \\
\hline Petani & 41,67 \\
1. & Sendiri & 23,33 \\
2. & Bank & 30,00 \\
3. & Sendiri dan \\
& Bank \\
4. & Pemerintah & 1,67 \\
5. & Kerabat & 1,67 \\
6. & Shorum & 1,67 \\
\hline Pedagang besar, pengecer, keliling \\
1. $\quad$ Investor & 4,00 \\
2. & Pedagang Lain \\
3. & Sendiri & 12,00 \\
4. & Bank & 72,00 \\
5. & Sendiri dan & 4,00 \\
\multicolumn{2}{l}{ Bank } \\
\hline Usaha & Pengolahan \\
1. & Sendiri \\
2. & Bank \\
3. & Sendiri, Bank, \\
\multicolumn{2}{l}{ dan Leasing } & Pemerintah \\
\hline
\end{tabular}

Kerjasama antar lembaga pemasaran merupakan sesuatu yang penting untuk memperlancar distribusi hasil panen. Setiap petani memiliki jaringan sendiri dalam memasarkan hasil panennya ke bandar-bandar yang sudah dikenal baik. Hal ini dikarenakan kepercayaan merupakan salah satu modal yang bandar yakini untuk mempercayakan hasil panennya dapat didistribusikan dengan baik. Harga jual yang lebih tinggi bisa menjadi pertimbangan petani menjual kepada bandar. Begitupun kerjasama antara bandar dengan pedagang besar ataupun pedagang besar dengan pedagang pengecer, serta pedagang pengecer dengan konsumen dan pedagang sayur keliling.

Selain modal kepercayaan, lembaga pemasaran saling mempertahankan kualitas hasil panen yang baik sesuai permintaan. Kualitas kentang yang baik, di antaranya berukuran besar, daging kentang berwarna kuning, kulit kentang bersih, tidak terkelupas, tidak tercangkul atau busuk. Adapun fungsi-fungsi pemasaran pada lembaga pemasaran kentang granola dapat dilihat pada Tabel 3.

\section{Analisis Saluran Pemasaran Kentang Granola}

Kotler (2003) dan Levens (2010) menjelaskan saluran pemasaran sebagai jaringan semua pihak yang saling terkait satu sama lain dalam mengalirkan barang maupun jasa yang berawal dari produsen sampai ke konsumen. Penelitian ini menghasilkan 9 saluran pemasaran kentang granola, diantaranya :

1. Saluran 1: petani-bandar-pedagang besar (pasar induk)-pedagang pengecer (pasar)-rumah makan dan pedagang makanan

2. Saluran 2: petani-bandar-pedagang besar (pasar induk)-pedagang pengecer (pasar)-pedagang sayurkonsumen akhir

3. Saluran 3: petani-perusahaan ekspor 
Tabel 3. Fungsi-Fungsi Pemasaran Kentang Granola

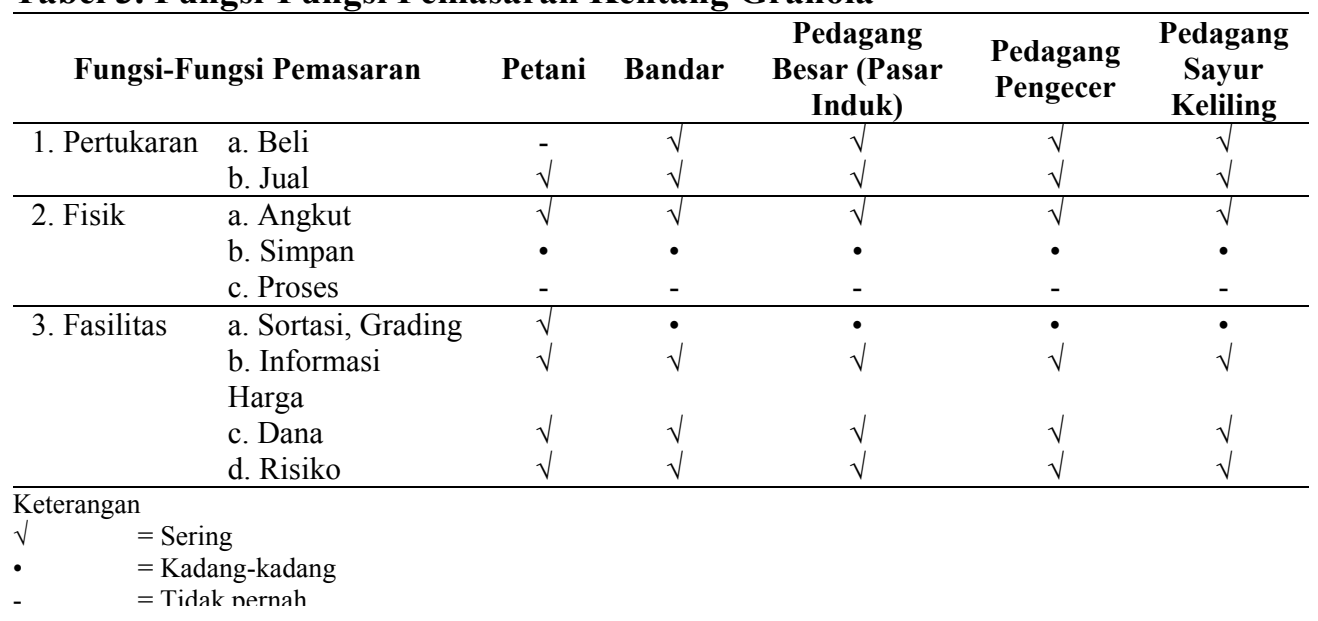

4. Saluran 4: petani-pedagang besar (pasar induk)-konsumen akhir

5. Saluran 5: petani-bandar-perusahaan ekspor

6. Saluran 6: petani-bandar-industri pengolahan

7. Saluran 7: petani-bandar-pedagang besar (luar kota)

8. Saluran 8: (petani+bandar)-peda-gang besar (pasar induk)-pedagang pengecer (pasar)-rumah makan dan pedagang makanan

9. Saluran 9: (petani+bandar)-peda-gang besar (pasar induk)-pedagang pengecer (pasar)-pedagang sayurkonsumen akhir.

Adapun saluran pemasaran kentang granola dari petani dapat dilihat pada Gambar 5.

Pada saluran ini dapat dilihat bahwa sebanyak 47 petani (78,33 persen) menjual langsung kentang granola segar kepada bandar dan sebanyak 12 orang (20 persen) menjual langsung kepada pedagang besar yang berada di pasar induk khususnya di Pasar Induk Pangalengan, dan 1 orang petani (10 persen) menjual ke perusahaan ekspor.

Bandar sebagai lembaga pemasaran pertama menjual kentang segar kepada pedagang besar pasar induk sebanyak 6 orang (60 persen), 2 orang (20 persen) menjual ke pedagang luar kota, 1 orang (10 persen) ke perusahaan ekspor, serta 1 orang (10 persen) ke usaha pengolahan. Terdapat 3 petani yang merangkap pekerjaan sebagai bandar dimana hasil panen didistribusikan langsung kepada pedagang besar pasar induk. Dengan adanya modal kepercayaan yang kuat, petani sekaligus bandar ini dapat menembus pasar induk dengan mudah.

Ukuran efisiensi adalah kepuasan konsumen, produsen, maupun lembagalembaga yang terlibat di dalam mengalirkan barang/jasa mulai dari petani hingga konsumen akhir (Asmarantaka, 2012). Pemasaran yang efisien terjadi apabila terdapat indikator- 


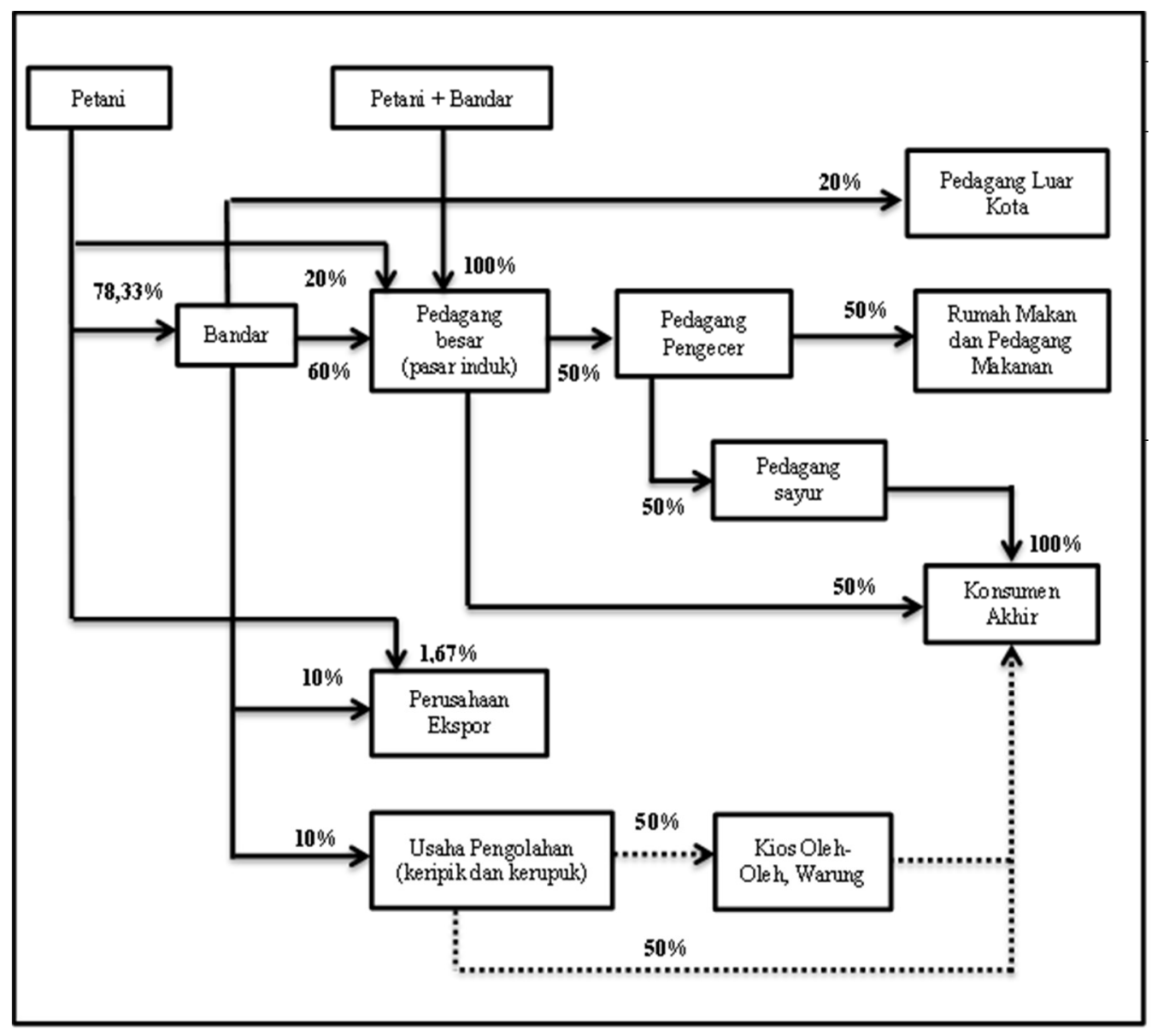

\section{Gambar 5. Pemasaran Kentang Granola dari Petani}

indikator, diantaranya menciptakan atau meningkatkan nilai tambah terhadap produk agribisnis, menghasilkan keuntungan bagi setiap lembaga pemasaran yang terlibat sesuai dengan biaya-biaya yang dikeluarkan, biaya dan marjin yang terjadi relatif sesuai dengan fungsi-fungsi atau aktivitas bisnis yang meningkatkan kepuasan konsumen akhir, serta memberikan bagian yang diterima petani yang relatif akan mendorong petani berproduksi di tingkat usahatani.
Konsentrasi terbesar berada pada lembaga pemasaran yaitu bandar dan pedagang besar karena terjadi perputaran penjualan yang cepat sehingga keuntungan yang diterima juga cukup besar. Saluran pemasaran ketiga merupakan saluran pemasaran yang cukup efisien dikarenakan petani langsung mendistribusikan kepada perusahaan ekspor dengan harga jual yang cukup tinggi, yaitu $\mathrm{Rp} 9.000$ per kg. 
Tabel 5. Kinerja Pemasaran Kentang Granola

\begin{tabular}{crrrr}
\hline Saluran & \multicolumn{1}{c}{$\begin{array}{c}\text { Total Biaya } \\
(\mathbf{R p} / \mathbf{k g})\end{array}$} & $\begin{array}{c}\text { Total Marjin } \\
\mathbf{( \% )}\end{array}$ & $\boldsymbol{\pi} / \mathbf{C}(\mathbf{\%})$ & $\begin{array}{c}\text { Farmer Share } \\
\mathbf{( \% )}\end{array}$ \\
\hline 1 & $2.050,10$ & 35,42 & 0,58 & 64,58 \\
2 & $3.981,10$ & 50,67 & 0,53 & 49,33 \\
3 & - & - & - & 100,00 \\
4 & 253,27 & 24,47 & 5,81 & 75,53 \\
5 & 20,00 & 34,22 & 153,00 & 65,78 \\
6 & 100,00 & 26,00 & 19,80 & 74,00 \\
7 & 236,83 & 11,20 & 2,15 & 88,80 \\
8 & $1.372,72$ & 23,89 & 0,56 & 76,11 \\
9 & $3.305,72$ & 42,92 & 0,56 & 57,08 \\
\hline
\end{tabular}

Berdasarkan efisiensi pemasaran setiap saluran dihasilkan nilai pada saluran pertama sebesar 22,36 persen, saluran 33,17 persen, saluran tiga nol persen (karena pendistribusian langsung), saluran empat sebesar 3,33 persen, saluran 5 sebesar 0,22 persen, saluran enam sebesar 1,25 persen, saluran ketujuh 3,55 persen, saluran delapan 15,27 persen, saluran sembilan sebesar 27,54 persen. Kesembilan saluran pemasaran kentang granola dinilai sudah cukup efisien dengan nilai farmer share yang diterima lebih dari 50 persen. Walaupun pada saluran kedua nilai farmer share hanya mencapai 49,33 persen saja.

\section{Analisis Kinerja Pasar}

Kinerja pasar dapat dilihat dari beberapa aspek, yaitu marjin pemasaran dan farmer share serta keuntungan per biaya $(\pi / \mathrm{c})$. Adapun perhitungan marjin, farmer share dan $\pi / \mathrm{c}$ dapat dilihat pada Tabel 4:

\section{Marjin Pemasaran}

Marjin pemasaran merupakan perbedaan harga di tingkat konsumen dengan harga yang diterima petani (Tomek dan Robinson, 1990). Kinerja pemasaran kentang granola di Pangalengan menunjukkan kinerja yang relatif efisien dimana marjin yang dihasilkan dari sembilan saluran menghasilkan ratarata 27,64 persen. Marjin tertinggi terdapat pada saluran kedua dengan nilai sebesar 50,67 persen dikarenakan pada saluran kedua lembaga pemasaran yang terlibat didalamnya cukup banyak sehingga total biaya yang dikeluarkan pun cukup besar, yaitu Rp 3.981,10 per $\mathrm{kg}$. Total marjin di saluran ketiga tidak ada karena petani menjual atau mendistribusikan langsung kepada perusahaan ekspor sehingga tidak ada lembaga pemasaran yang terlibat di dalamnya.

Total marjin saluran sembilan adalah terbesar kedua dengan nilai sebesar 42,92 persen dengan total biaya yang dikeluarkan adalah Rp 3.305,72 per $\mathrm{kg}$. Perbedaan harga antara saluran kedua dan sembilan dikarenakan pada saluran sembilan terdapat peran ganda antara petani dan bandar. Petani pada saluran 
Tabel 6. Persentase Total Marjin Pemasaran Kentang Granola

\begin{tabular}{crrrrr}
\hline & \multicolumn{5}{c}{ Persentase Total Marjin } \\
\cline { 2 - 6 } Saluran & \multicolumn{1}{c}{ Bandar } & $\begin{array}{c}\text { Pedagang Besar } \\
\text { (Pasar Induk) }\end{array}$ & $\begin{array}{c}\text { Pedagang } \\
\text { Pengecer }\end{array}$ & $\begin{array}{c}\text { Pedagang } \\
\text { Sayur }\end{array}$ & \multicolumn{1}{c}{ Total } \\
\hline 1. & 23,78 & 11,03 & 65,20 & - & 100,00 \\
2. & 12,70 & 5,89 & 34,82 & 46,60 & 100,00 \\
3. & - & - & - & - & 100,00 \\
4. & - & 100,00 & - & - & 100,00 \\
5. & 100,00 & - & - & - & 100,00 \\
6. & 100,00 & - & - & - & 100,00 \\
7. & 100,00 & - & - & - & 100,00 \\
8. & - & 16,28 & 83,72 & - & 100,00 \\
9. & - & 6,80 & 34,95 & 58,25 & 100,00 \\
\hline
\end{tabular}

sembilan menjual langsung kepada pedagang besar yang berada di pasar induk sehingga dapat menekan biaya pengeluaran dalam pemasaran kentang granola.

Tabel 5 menunjukkan perhitungan persentase total marjin pemasaran kentang granola pada setiap lembaga pemasaran mulai dari bandar hingga pedagang sayur keliling. Persentase Total marjin pemasaran kentang granola dapat dilihat bahwa pada saluran satu, pedagang pengecer lebih besar mendapatkan marjin sebesar 65,20 persen sedangkan pada saluran kedua sebesar 46,60 persen oleh pedagang sayur. Untuk saluran kedelapan pedagang pengecer mendapatkan persentase terbesar yaitu 83,72 persen dan saluran terakhir pedagang pengecer mendapatkan marjin sebesar 58,25 persen.

Persentase total keuntungan pada lembaga pemasaran bertujuan untuk menghitung keuntungan yang didapat lembaga pemasaran dibagi dengan total keuntungan di saluran tersebut. Hasil penelitian menunjukkan bahwa saluran pertama total keuntungan pedagang pengecer sebesar 46,54 persen dan bandar 44,71 persen. Hal ini disebabkan harga jual kentang yang dilakukan oleh pedagang pengecer jauh lebih tinggi dibandingkan dengan bandar yang menjual ke pedagang besar di pasar induk. Saluran kedua merupakan saluran terpanjang dengan total keuntungan masing-masing lembaga pemasaran, yaitu 24,50 persen bandar, 4,99 persen pedagang besar di pasar induk, 26,54 persen pedagang pengecer, dan 42,97 persen pedagang sayur keliling. Hal ini dapat dilihat pada Tabel 6 .

Share pada setiap saluran lembaga pemasaran berbeda-beda. Hal ini dapat disimpulkan bahwa semakin sedikitnya lembaga pemasaran yang terlibat di dalam pemasaran maka akan semakin rendah total marjin yang didapat dalam saluran pemasaran. Begitupun sebaliknya, semakin banyak lembaga pemasaran yang terlibat maka akan semakin besar total marjin yang akan didapat.

\section{Farmer Share}

Kohls dan Uhl (2002) menjelaskan farmer share adalah perbedaan harga pengecer dan marjin pemasaran. Hasil penelitian menjelaskan saluran ketiga 
Tabel 7. Persentase Total Keuntungan Pemasaran Kentang Granola

\begin{tabular}{crrrrr}
\hline & \multicolumn{5}{c}{ Persentase Total Keuntungan } \\
\cline { 2 - 6 } Saluran & Bandar & $\begin{array}{c}\text { Pedagang Besar } \\
\text { (Pasar Induk) }\end{array}$ & $\begin{array}{c}\text { Pedagang } \\
\text { Pengecer }\end{array}$ & $\begin{array}{c}\text { Pedagang } \\
\text { Sayur }\end{array}$ & Total \\
\hline 1. & 44,71 & 8,75 & 46,54 & - & 100,00 \\
2. & 25,50 & 4,99 & 26,54 & 42,97 & 100,00 \\
3. & - & - & - & - & 100,00 \\
4. & - & 100,00 & - & - & 100,00 \\
5. & 100,00 & - & - & - & 100,00 \\
6. & 100,00 & - & - & - & 100,00 \\
7. & 100,00 & - & - & - & 100,00 \\
8. & - & 28,41 & 71,59 & - & 100,00 \\
9. & - & 11,94 & 30,09 & 57,96 & 100,00 \\
\hline
\end{tabular}

memiliki farmer share 100 persen (tertinggi bila dibandingkan dengan saluran lainnya) dikarenakan saluran tersebut langsung dari petani ke perusahaan ekspor. Hal ini belum tentu menunjukkan bahwa saluran ini paling efisien. Keuntungan per biaya pada saluran ke-1,2,8, dan 9 masih menunjukkan nilai dibawah satu yang berarti bahwa saluran tersebut masih belum mendapatkan keuntungan maksimal (Tabel 4).

Saluran ketujuh memiliki farmer share sebesar 88,8 persen. Saluran kedelapan dan keempat memiliki farmer share di atas 75 persen, yaitu masingmasing 76,11 persen dan 75,53 persen. Saluran keenam dengan nilai farmer share sebesar 74 persen. Saluran ke-1 dan kelima memiliki farmer share sebesar 64,58 persen dan 65,78 persen, saluran ke-9 sebesar 57,08 persen, dan saluran kedua sebesar 49,33 persen.

\section{SIMPULAN DAN SARAN Simpulan}

Hasil penelitian memberikan simpulan berdasarkan tujuan penelitian, yaitu struktur pasar komoditas kentang granola cenderung oligopsoni. Struktur pasar menunjukkan konsentrasi lemah dan terjadi hambatan masuk. Hal ini diindikasikan dengan sulitnya menjadi seorang bandar, karena dibutuhkan modal yang cukup besar, kepercayaan yang tinggi, jaringan yang kuat. Adapun perilaku pasar masih mengandalkan bandar dan pedagang besar dalam mekanisme harga serta pemasaran kentang segar, sedangkan kinerja pasar dinilai relatif efisien.

\section{Saran}

Berdasarkan hasil analisis dan simpulan yang diperoleh, maka dapat dirumuskan beberapa saran implikasi kebijakan, diantaranya : 
1. Diperlukan penerapan kelembagaan yang baik dengan cara menghidupkan kembali gabungan kelompok tani (gapoktan) untuk peningkatan marjin maupun profit khususnya petani kentang granola dan pelaku usaha lainnya.

2. Informasi pasar harus transparan diketahui oleh pelaku pasar demi berjalannya mekanisme pasar yang lebih baik.

3. Pemerintah memberikan jaminan pasar terhadap harga kentang agar petani dapat memiliki bargaining position atau posisi tawar terhadap lembaga pemasaran lainnya

\section{DAFTAR PUSTAKA}

Agustian A, Mayrowani H. 2008. Pola Distribusi Komoditas Kentang di Kabupaten Bandung, Jawa Barat. Jurnal Ekonomi Pembangunan. Vol 9(1): 96-106.

Asmarantaka RW. 2012. Pemasaran Agribisnis (Agrimarketing). Departemen Agribisnis, FEM IPB. Bogor.

Chan JO. 2007. A Predictive Analytic Model For Value Chain Management. Journal of International Technology and Information Management. Vol 6(1): 31-43.

Dahl DC, Hammond JW. 1977. Market and Price Analysis. Mc. Graw Hill, New York.
Dinas Pertanian tanaman Pangan Provinsi Jawa Barat. 2012. Harga Kentang di Beberapa Pasar Induk Tahun 2012. Jakarta (ID).

Direktorat Jenderal Hortikultura. 2014. Rencana Strategis Direktorat Jenderal Hortikultura Tahun 20102014. Jakarta (ID).

Higgins A, Thorburn P, Archer A, and Jakku E. 2007. Opportunities for Value Chain Research in Sugar Industries. Agricultural Systems 94: 611-621.

Hirschey M. 2009. Managerial Economics: An Integrative Approach. New Delhi (IN). Cengage Learning.

Irawan B. 2007. Fluktuasi Harga, Transmisi Harga, dan Marjin Pemasaran Sayuran dan Buah. Analisis Kebijakan Pertanian. Vol 5(4): 358-373.

Jaya WK. 2001. Ekonomi Industri. Edisi Kedua. Yogyakarta (ID). Fakultas Ekonomi Pr, Universitas Gajah Mada.

Kohls RL, Downey WD. 1972. Marketing of Agricultural Products 4th edition. Macmillan Publishing. New York.

Kohls RL, Uhl JN. 2002. Marketing of Agricultural Products. Prentice Hall. New Jersey.

Levens M. 2010. Marketing : Defined, Explained, Applied. International Edition. Pearson : Prentice Hall. 
Pietrobelli C, and Rabellotti R. 2011. Global Value Chain Meet Innovation System : Are There Learning Opportunities for Developing Countries?. World Development. Vol 39(7): 12611269.

[Pusdatin] Pusat Data dan Sistem Informasi Pertanian Kementrian Pertanian. 2013. Statistik Harga Komoditas Pertanian. Jakarta (ID).

Sukayana IM, Darmawan DP, dan Wijayanti NPU. 2013. Rantai Nilai Komoditas Kentang Granola di

Desa Candikuning Kecamatan Baturiti Kabupaten Tabanan. EJurnal Agribisnis dan Agrowisata. Vol 2(3): 99-108.

Tomek GW, Robinson KL. 1990. Agricultural Product Prices. Cornell University Press, Ithaca 